\title{
Durability study of lightweight concrete material made from date palma seeds (DPS)
}

\author{
M. Almograbi \\ Nasser Nations University, Tripoli, Libya
}

\begin{abstract}
Libya is one of the largest producers of dates from date palm, generating about 60000 tonnes of date palm seeds (DPS) annually. This large amount of seeds led to studies into the possible use as aggregates in lightweight concrete for some special structures. The utilization of DPS as aggregate in concrete provides a good solution as alternative aggregate to the stone aggregate. It has been recognized that, DPS can be used as coarse aggregate in structural lightweight concrete industry. For any structure member, the durability is one of the most important considerations during its service life. This paper presents the durability properties of DPS concrete. These include the water permeability, water absorption, sorptivity and chloride penetration. The test results obtained were comparable to the conventional lightweight concrete.
\end{abstract}

Keywords: date palm seeds, lightweight concrete, durability, sustainability, permeability of concrete, water absorption of concrete, sorptivity of concrete.

\section{Introduction}

Engineers have been developing new technologies for sustainable materials in the construction industry. One of such technologies is to use waste materials as building materials. DPS is a renewable resource and therefore, has significant potential in the construction industry where date palm is in abundance. This is particularly so in Libya. Currently, the large quantity of DPS waste has led to studies focusing on the possible use of this waste as aggregates in special structural lightweight concrete.

It has been reported that the concrete industry globally would consume around 8 to 12 billion tones annually of natural aggregates after the year 2010 [1]. 
Therefore, the use of DPS as aggregates in concrete would minimize the uses of stones and gravels.

DPS is lightweight in nature and consequently, the resulting concrete is also lightweight. This will, significantly reduces the total dead load of a structure, which result in smaller structure members.

\section{Date palm seeds (DPS) aggregate}

The palm dates are red to brown when ripe and it is almost spherical, ellipsoid or elongated in shape. Each palm date consists of a hard seed inside it. The seeds can be collected, cleaned, dried and used as coarse aggregate.

The properties of the DPS aggregates used in the current investigation are shown in Table 1.

Table 1: $\quad$ Properties of the DPS aggregates.

\begin{tabular}{|c|c|}
\hline Properties & DPS aggregate \\
\hline Maximum aggregate size, $\mathrm{mm}$ & $15 \mathrm{~mm}$ \\
\hline Bulk density, $\mathrm{kg} / \mathrm{m}^{3}$ & 584 \\
\hline Specific gravity & 1.13 \\
\hline Fineness modulus & 5.88 \\
\hline Los Angeles abrasion value $\%$ & 5.1 \\
\hline Aggregate impact value $\%$ & 6.83 \\
\hline Aggregate crushing value $\%$ & 7.1 \\
\hline 24-hour water absorption $\%$ & 36 \\
\hline
\end{tabular}

\section{DPS concrete mix}

The mix design of lightweight concrete is different from that of ordinary one. In this study, a number of trial mixes were produced and the acceptable mixes were selected. The optimum DPS concrete mix selected was comprised of $500 \mathrm{~kg} / \mathrm{m}^{3}$ cement (C), $310 \mathrm{~kg} / \mathrm{m}^{3}$ DPS (DPS), $820 \mathrm{~kg} / \mathrm{m}^{3}$ sand (S) and superplasticiser of 1.5 liters per $100 \mathrm{~kg}$ of cement with a w/c ratio of 0.37 . The ratio of $\mathrm{C}: \mathrm{S}$ : DPS by volume was equivalent to 1:2.2:1.50, with the fine and coarse aggregates occupying approximately 77 percent of the total volume of the DPS concrete content.

\section{Curing conditions}

In this study, two curing methods adopted in-situ were considered. S1 and S2 consisted of 3 and 7 days moist curing respectively.

For both S1 and S2, the exposure site was unobstructed from wind, sun radiation and rainfall. In this study, the atmospheric temperatures ranged from $36^{\circ} \mathrm{C} \pm 5^{\circ} \mathrm{C}$ with humidity less than $15 \%$. The curing conditions are illustrated in Table 2 . 
Table 2: $\quad$ Adopted curing methods.

\begin{tabular}{|c|c|c|c|c|}
\hline \multirow{2}{*}{$\begin{array}{c}\text { Curing } \\
\text { type }\end{array}$} & \multirow{2}{*}{ Symbol } & \multicolumn{3}{|c|}{ Duration of curing, (days) } \\
\cline { 3 - 5 } & & $\begin{array}{c}\text { Outdoor } \\
\text { (plastic cover) }\end{array}$ & $\begin{array}{c}\text { Outdoor } \\
\text { (wet burlap) }\end{array}$ & $\begin{array}{c}\text { Outdoor } \\
\text { (exposed) }\end{array}$ \\
\hline 3-days & S1 & 3 & - & Until age of test \\
\hline 7-days & S2 & 1 & 6 & Until age of test \\
\hline
\end{tabular}

\section{Test specimen and test method}

The durability properties of DPS concrete were determined at the ages of 28, 56 and 90 days, through several tests which include water permeability, water absorption, sorptivity and chloride penetration.

The procedure of Teo et al. [2], for light weight concrete from oil palm shell has been followed in this investigation.

\subsection{Water permeability test}

The permeability test was done using a $150 \mathrm{~mm}$ x $150 \mathrm{~mm}$ x $75 \mathrm{~mm}$ thick concrete specimens. The concrete specimens were subjected to a pressure of 30 bars $(3 \mathrm{MPa})$ using a pressure permeability cell. When constant flow was achieved, the quantity of water collected and corresponding duration were recorded (Tsivilis et al. [3]). The coefficient of permeability was computed using the following equation

$$
k=\frac{C_{c} \times h}{A \times t \times P}
$$

where $C_{c}$ is the volume of water collected $\left(\mathrm{cm}^{3}\right), h$ is the height of specimen (cm), $A$ is the area of specimen $\left(\mathrm{cm}^{3}\right), t$ is the time (sec), and $P$ is the pressure (cm of water column).

\subsection{Water absorption test}

To obtain the water absorption, a $100 \mathrm{~mm}$ cube specimens was used. The specimens were dried to constant mass and immersed in water. The increase in mass was measured as a percentage of dry mass [4].

\subsection{Sorptivity test}

$100 \mathrm{~mm}$ cube specimens were used to determine the rate of capillary rise through absorption of concrete surface. The testing was done on the moulded face of the specimens. The uptake of water by capillary rise was measured through weight gain at set intervals of 5,10,20,30, 45, 60 and 120 minutes after starting the test. Since the cumulative absorbed volume per unit area of the inflow surface, denoted $(i)$, increased as the square root of the elapsed time $(\mathrm{t})$, the sorptivity $(\mathrm{S})$ 
is defined as the slope of the $i$ against $(t)^{0.5}$ plot and is determined using regression analysis $[3,5]$.

\subsection{Silver nitrate test}

The silver nitrate test is used to determine the chloride penetration depth. For this test, concrete panel specimens were cured and ponded with 3\% sodium chloride solution for 90 days (AASHTO T259) [6]. After ponding and wetting and drying cycles, specimens were split in half and the broken face of the specimen was sprayed with $0.1 \mathrm{~N}$ silver nitrate $(\mathrm{AgNO} 3)$ aqueous solution to determine the chloride penetration depth. The average depth of chloride penetration was determined by measuring at five locations along each face of the split specimen.

\section{Results and discussions}

\subsection{Water permeability test}

The permeability of concrete has a very high effect on its durability. Concretes with high permeability allow easy access of water, which affect the materials in the concrete mass, and may cause corrosion of the embedded reinforcement.

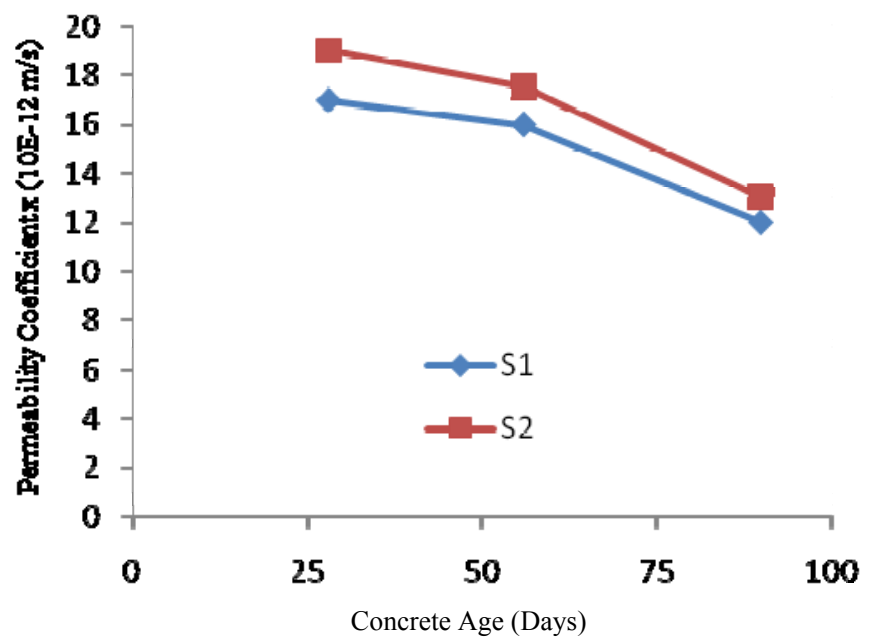

Figure 1: Water permeability of DPS concrete.

The water permeability of DPS concrete is illustrated in Figure 1. Although DPS aggregates are porous in nature, the resulting DPS concrete was reasonably impermeable. Within the concrete matrix, the porous palm seeds are not interconnected, but each seed is surrounded by the cement paste. Since the w/c ratio of DPS concrete is low, at 0.37 , the cement paste is of reasonable quality, 
thereby producing a concrete with low permeability. It was found that lightweight concretes made from pumice aggregates has, a comparable permeability values ranging from $6 \times 10^{-12}$ to $13 \times 10^{-12} \mathrm{~m} / \mathrm{sec}$ [7]. It was also observed that the two differently cured specimens had similar permeability coefficients, which showed that both curing methods provided similar level of effectiveness in terms of permeability.

\subsection{Water absorption test}

Due to the higher porosity of the lightweight aggregate, the water absorption of the lightweight concretes is generally higher than, that of the normal weight concretes. The water absorption rate for DPS concrete is shown in Figure 2. These results were comparable to other conventional lightweight concretes [8].

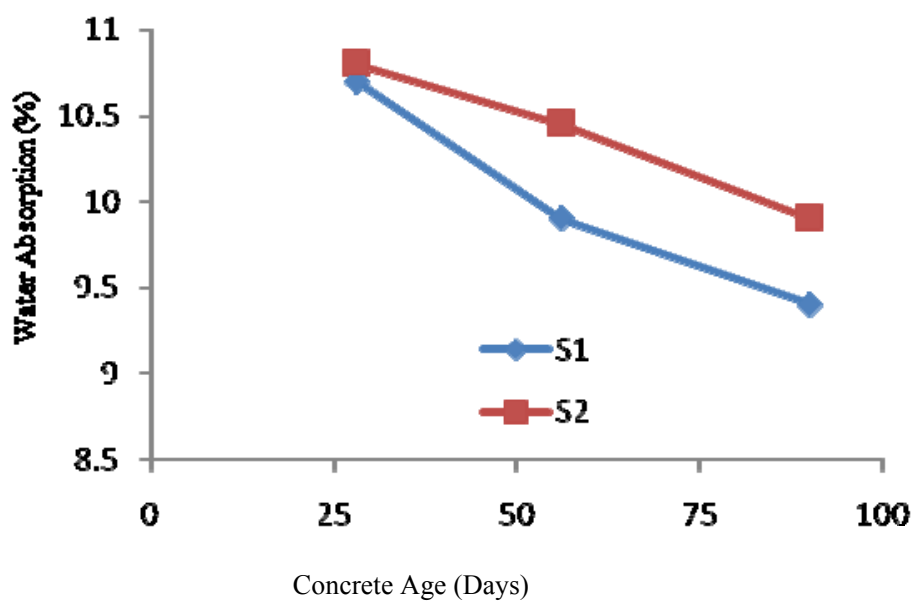

Figure 2: Water absorption of DPS concrete.

\subsection{Sorptivity test}

The sorptivity gives a good indication of the pore concrete. Lower sorptivity values indicate higher resistance of concrete towards water absorption. Generally, high quality concretes have sorptivity values of less than $0.1 \mathrm{~mm} / \mathrm{min}$ 0.5 [9]. From Figure 3, the sorptivity of DPS concrete ranges from about 0.04 to $0.07 \mathrm{~mm} / \mathrm{min} 0.5$. 


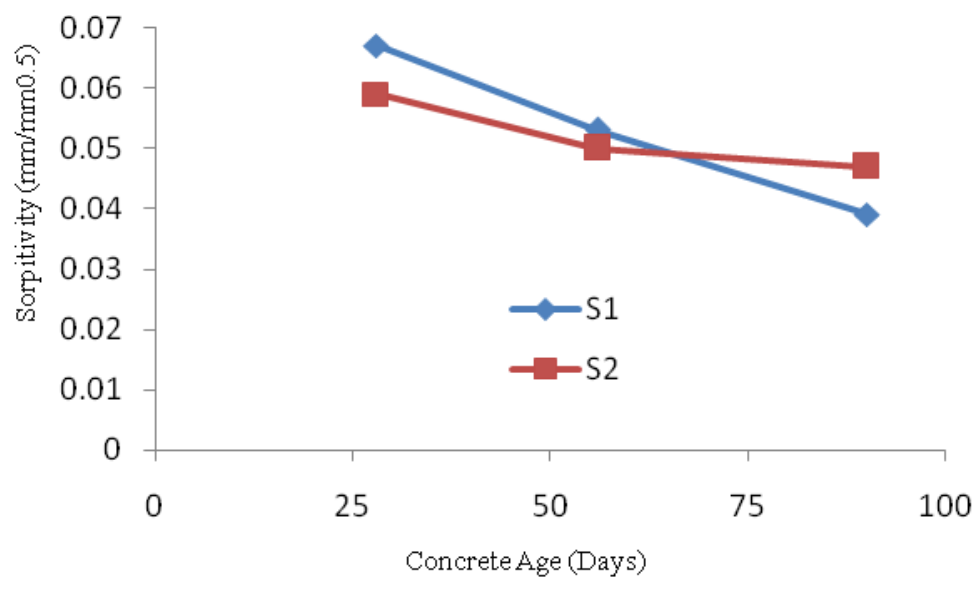

Figure 3: $\quad$ Sorptivity of DPS concrete.

\subsection{Silver nitrate test}

The purplish color on the specimen shows the penetrated chloride and the measured depths to the chloride front for DPS concrete are presented in Table 3. There was a substantial increase in the chloride ingress of DPS concrete with increasing wetting and drying cycles. Micro cracks, which originally exist in the concrete, may increased and become interconnected when subjected to increased wetting and drying cycles causing higher chloride concentrations within the concrete specimen.

Table 3: $\quad$ Penetration depth of chloride for DPS concrete.

\begin{tabular}{|c|c|c|c|c|}
\hline \multirow{2}{*}{ Specimen } & \multicolumn{4}{|c|}{ Penetration depth, (mm) } \\
\cline { 2 - 5 } & $\begin{array}{c}\text { 90 days salt } \\
\text { ponding specimen }\end{array}$ & 4 cycles & 10 cycles & 30 cycles \\
\hline CS1 & 21 & 10 & 18 & 24 \\
\hline
\end{tabular}

\section{Conclusions}

The use of DPS as aggregates in concrete economies the natural resource and minimizes the environmental impact. The results obtained from this study provide good information for the durability of lightweight concrete produced from DPS. The, results shows that, the behavior of DPS concrete is similarly to the other conventional lightweight concretes in terms of durability properties. 


\section{References}

[1] Tu TY, Chen YY, Hwang CL. Properties of HPC with recycled aggregates. Cement and Concrete Research 2006; 36(5): 943-950.

[2] Teo D.C.L, Mannan M. A, Kurian V. J. Durability properties of structural lightweight concrete made from oil palm shell (OPS).

[3] Tsivilis S, Tsantilas J, Kakali G, Chaniotakis E, Sakellariou A. The permeability of Portland limestone cement concrete. Cement and Concrete Research 2003; 33(9): 1465-1471.

[4] Khatib JM, Mangat PS. Absorption characteristics of concrete as a function of location relative to casting position. Cement and Concrete Research 1995, p.235-259.

[5] Neville AM. Properties of Concrete. 4th ed. Malaysia: Longman; 1999.

[6] AASHTO T259. 1980. Standard Method of Test for Resistance of Concrete to Chloride Ion Penetration. American Association of State Highway and Transportation Officials.

[7] Hossain KMA. Properties of volcanic pumice based cement and lightweight concrete. Cement and Concrete Research 2004; 34(2): 283-291.

[8] Güdüz L, Uğur İ. The effects of different fine and coarse pumice aggregate/cement ratios on the structural concrete properties without using any admixtures. Cement and Concrete Research 2005; 35(9): 1859-1864.

[9] Euro Light Con. 2000. Properties of Lightweight Concretes Containing Lytag and Liapor, European Union - Brite Eu Ram III. Document BE963942/R8. 